\title{
Forskningsetikk, sannhet og kjærlighet
}

\author{
Vi bør i større grad vise nåde ved de minst alvorlige bruddene på god forskningspraksis. Straffende sank- \\ sjoner bør kun brukes ved de groveste bruddene.
}

Publisert først på nett 9.8. 2012

Jeg har i de siste måneder engasjert meg til fordel for en ph.d.-student ved mitt institutt som i vinter ble tvangsmessig utskrevet fra ph.d.-programmet ved Universitetet i Bergen, dømt for «grov uaktsomhet» ved at han hadde gjengitt tekst fra og mangelfullt referert to kilder i kappen til avhandlingn sin (1). Studenten ble utvist etter innstilling fra Fakultetsstyret ved Det medisinsk-odontologiske fakultet. Evalueringskomiteen mente at bruddene på god siteringspraksis var så alvorlige at avhandlingen burde refuseres, men flertallet ba senere om at studenten fikk anledning til å rette opp og levere på nytt. Utvisningen ble appellert til Universitetsstyret som opprettholdt straffen på tross av at tiltalen ble redusert fra overlagt fusk til grov uaktsomhet. Mine opplevelser i denne saken er selvsagt subjektive, og min fremstilling er preget av det: Studenten fikk ikke anledning til forsvarlig kontradiksjon. Universitetet følger en praksis med klagebehandling i samme institusjon som primærbehandlingen. Det er ikke habilitetsmessig forsvarlig. Administrasjonens innstilling på begge nivåer i saksbehandlingen var uten behørig hensyntaking til den fornærmede. Slik jeg har opplevd det, ble viktige dokumenter og redegjørelser fra den fornærmede underslått eller oversett. En benådning ville ikke hatt presedens da alle innleverte avhandlinger ved vårt universitet nå kontrolleres før innlevering ved hjelp av et tekstgjenkjenningsprogram.

\section{Læring eller straff}

Jeg har pasienter som er helsemessig skadet av krenkelser fra helsepersonell som ikke har vært i stand til å uttale: «jeg beklager» etter alvorlige uheldige hendelser. Tilsynsmyndighetene bidrar til slike krenkelser med juridiske prosedyrer for å fastslå fakta og sannhet, som om det var det eneste viktige. Ph.d.-studentens opplevelse av krenkelse er identisk med mine pasienters. Han bruker i samtale med meg ord som «nedbrutt, tapt fremtidstro, mister evnen til å forsørge mine barn» og liknende. Poenget mitt med denne sammenlikningen er å fortelle at vi i helsevesenet, i tilsynsmyndighetene og ved universitetene ofte glemmer at vi står overfor medmennesker. Vi glem-

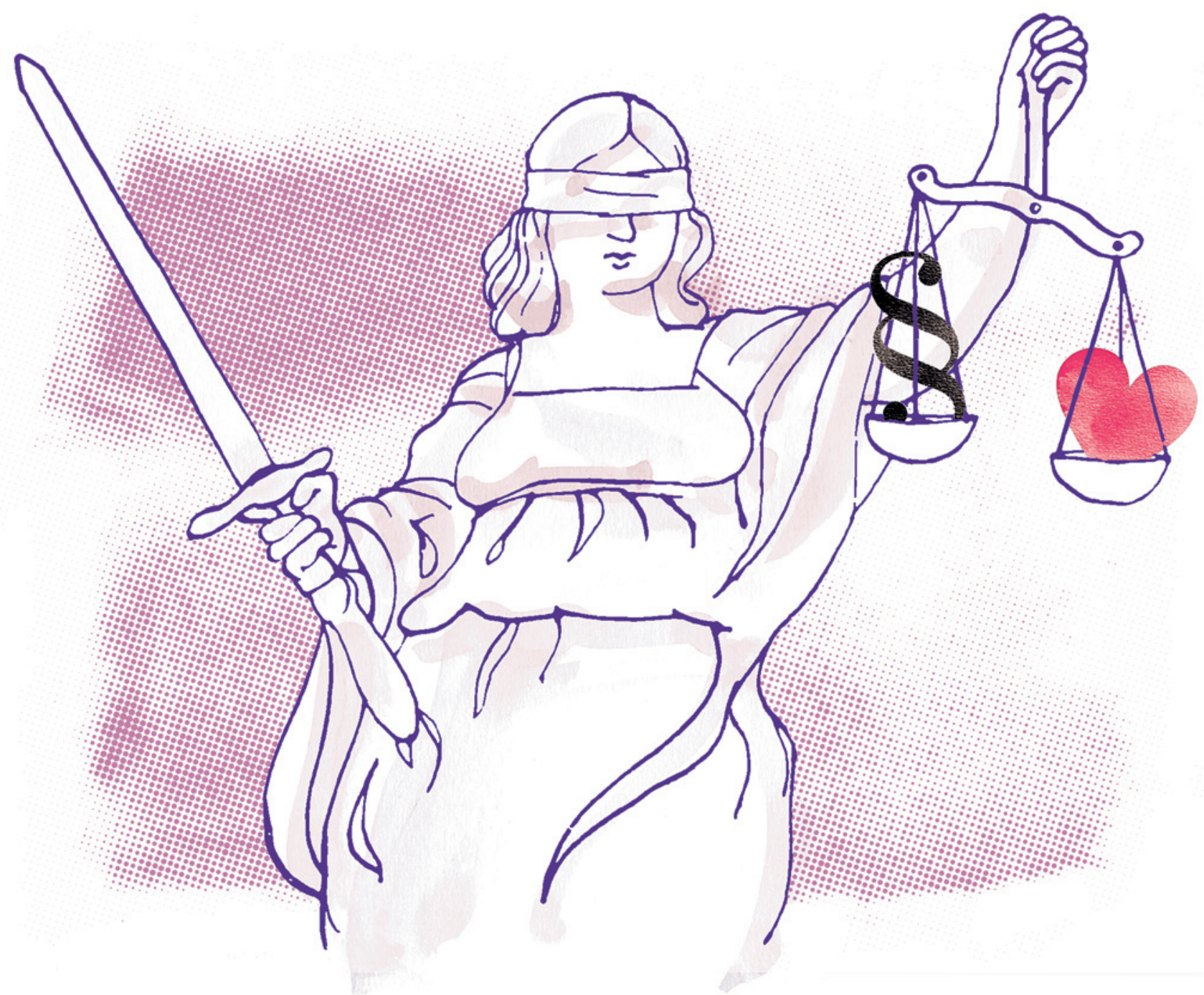


mer at sannhet er en del av en større moralsk sammenheng der kjærlighet og barmhjertighet har en viktig plass. Det er et gjensidig, men motsetningsfylt forhold mellom disse: uten kjærlighet blir sannheten til barbari, men uten sannhet blir kjærligheten til anarki.

Jesus fra Nasaret er sjelden sitert som kunnskapsteoretiker. Men hans tale til datidens professorer, fariseerne og de skriftlærde, inneholdt nettopp det budskap som er poenget mitt her. Han anklaget dem for å sette loven og prosedyrene over kjærligheten, barmhjertigheten og nåden (2).

Det er på den annen side nødvendig å fremme forskningsetiske normer. Derfor har vi fått forskningsetikkloven, regionale etiske komiteer og utvalg for gransking av redelighet i forskning. Men vi kan ikke late som om det går et skarpt skille mellom redelighet og uredelighet, og vi kan heller ikke entydig definere hva som bør håndteres som pedagogiske utfordringer og hva som skal håndteres med straff. Dette er et viktig poeng i Arild Raaheims bok om læring og undervisning i høyere utdanningsinstitusjoner (3). Uredeligheten opptrer i alle former fra selvplagiering, bortlån av eget navn til andres publikasjoner, plagiering av egne forskningsresultater (dobbeltpublisering), «tyning» av data, bruk av andres tekst(fragment)er uten adekvat kildehenvisning, selektiv datapresentasjon, plagiering av andres forskningsresultater, og til det mest ekstreme med fabrikkering av data og resultater.

\section{Perfeksjonistiske fryktkabinetter}

Jeg vil anbefale at vi følger normer som anviser pedagogiske metoder ved de minst alvorlige bruddene på god forskningspraksis, men anvender straffende sank- sjoner mot de groveste brudd på forskningsetikken. Jeg vil også bidra til at vi viser nåde mot nybegynnere i større grad enn mot rutinerte forskere og akademikere. Hvis vi ikke klarer det, vil akademiet lett få preg av nepotisme og hykleri. Vi er alle tjent med at vi klarer å påvirke den forskningsetiske kulturen gjennom årvåken og kritisk dialog og lærende prosesser i størst mulig grad. I helsevesenet har vi i de senere år prøvd å utvikle en åpen feilbarlighetskultur, der feil er utgangspunkt for læring. Vi akademikere er ansvarlig for at universitetene ikke går i motsatt retning og får preg av perfeksjonistiske fryktkabinetter.

Når det er vanskelig å vinne aksept for en slik fremgangsmåte i akademiet, er det lett å bli personfokusert og indignert på enkelte aktører. For meg har det størst interesse å analysere systemfaktorers betydning. I likhet med Knud Løgstrup (dansk etisk filosof og teolog, 1905-81), mener jeg at moralens problem $i$ vår samtid kan skyldes moralfilosofiens ensidige interesse for å utøve moralske prinsipper. Dette kan føre til et ytre forhold til moralen, til moralisme og til moralsk utarming (4). Andre bruker begrepet «moralsk schizofreni». En slik utarming og schizofreni har smittet fra moralens område til pedagogikken. Forholdet mellom institusjon og student preges av et ytre forhold ved at målsettingen utelukkende er kunnskapsformidling, mens dannelse i et moralsk fellesskap mellom lærer og student neglisjeres. Nåden og kjærligheten kan forsvinne når læringen utelukkende blir et middel til å kvalifisere til og fostre akademisk kompetanse (5). I tillegg utarmes akademiet av en spesiell form for moralsk likegyldighet. Vitenskapelig metode blir en livssynserstatning. Tvil og vitenskapelig kritisk metode blir til tro (6).

\section{Kjærlighet > sannhet}

Jesu oppgjør med fariseerne og de skriftlærde var nådeløs i sin retorikk. Han kalte dem «hvitkalkede graver og ormeyngel» (2). Det er en språkbruk som i dag ikke vil stimulere til dialog. Som et alternativ vil jeg foreslå at vi sammen reflekterer over et kinesisk ordtak: Kjærligheten er større enn sannheten! Våger vi å ta dette inn over oss?

\section{Eivind Meland}

eivind.meland@isf.uib.no

Eivind Meland (f. 1950) er spesialist i allmennmedisin, fastlege ved Olsvik legesenter og professor ved Institutt for samfunnsmedisinske fag, Universitetet i Bergen.

Forfatter har fylt ut ICMJE-skjemaet og oppgir følgende interessekonflikt: Han har, sammen med 30 andre ansatte ved Universitetet i Bergen, garantert for et beløp som skal bidra til å dekke ph.d.-kandidatens saksomkostninger dersom universitetet ikke betaler.

Litteratur

1. Meland E. Forskningsetikk - eller nådeløs moralisme? Bergens Tidende 15.2.2012: 30.

2. Bibelen. Matt 23, 23-34.

3. Raaheim A. Læring og undervisning. Bergen: Fagbokforlaget, 2011.

4. Løgstrup KE. Den etiske fordring. Trondheim: Cappelen, 2000

5. Sanger M. The schizophrenia of contemporary education and the moral work of teaching. Curric Inq 2012; 42: 285-307.

6. Hoffmeyer J. Tro på tvivl. Kritik av religiøs og videnskabelig ufornuft. Charlottenlund: Forlaget Ries, 2009.

Mottatt 11.6. 2012, første revisjoln innsendt 20.6. 2012, godkjent 28.6. 2012. Medisinsk redaktør Kristin Viste. 